\title{
Realized pollen flow and wildling establishment from a genetically modified eucalypt field trial in Southeastern Brazil
}

\author{
Paulo H.M. da Silva ${ }^{\mathrm{a}, \mathrm{b}, *}$, Alexandre M. Sebbenn ${ }^{\mathrm{c}, \mathrm{d}}$, Dario Grattapaglia ${ }^{\mathrm{e}, \mathrm{f}}$, José Luiz F. Conti Jr. ${ }^{\mathrm{g}}$ \\ a Instituto de Pesquisas e Estudos Florestais (IPEF), Avenida Pádua Dias 11, Caixa Postal 530, CEP 13400-970 Piracicaba, SP, Brazil \\ ${ }^{\mathrm{b}}$ Graduate Program in Forest Sciences FCA/UNESP, Botucatu, SP CEP 18610-307, Brazil \\ c Instituto Florestal de São Paulo, CP 1322, São Paulo, SP CEP 01059-970, Brazil \\ ${ }^{\mathrm{d}}$ Faculdade de Engenharia de Ilha Solteira/UNESP, Caixa Postal, 31, Ilha Solteira, SP CEP 15385-000, Brazil \\ e Plant Genetics Laboratory, EMBRAPA Genetic Resources and Biotechnology, CEP 70770-970 DF, Brasilia, Brazil \\ ${ }^{\mathrm{f}}$ Graduate Program in Genomic Sciences Biotechnology and Universidade Católica de Brasília, SGAN Qd 916, CEP 70790-160 DF, Brasília, Brazil \\ ${ }^{\mathrm{g}}$ ArborGen Tecnologia Florestal, Rua Dr. Emilio Ribas n.174, CEP13025-140 Campinas, SP, Brazil
}

\section{A R T I C L E I N F O}

\section{Article history:}

Received 30 August 2016

Accepted 23 November 2016

Available online 2 December 2016

\section{Keywords:}

Genetically modified (GM) tree

GM pollen flow

Buffer zones

GM wildling establishment

\begin{abstract}
A B S T R A C T
Confined field trials of genetically modified (GM) trees are the essential step toward the identification of the most productive cultivars and the assessment of the likely environmental impacts of the GM trees including the potential for gene flow by pollen and distance dispersal by seeds. Our study investigated the potential for wildling establishment and realized pollen flow from a clonal GM eucalypt field trial in Southeastern Brazil. The GM eucalypt stand was established in 2009, surrounded by a $3 \mathrm{~m}$ wide forest road and signal grass (Bracharia sp.) fields. No seedling regeneration was found between 2010 and 2014 in and around the stand, confirming the expectations of the unlikelihood of eucalypt seedling establishment based on its limited invasive potential in competitive tropical environments. In 2014, openpollinated seeds were collected from 28 non-GM eucalypts located between three and $650 \mathrm{~m}$ distance from the GM trial. A total of 420 seedlings were grown in a greenhouse and screened for the presence of the transgenic construct by a multiplexed PCR assay targeting two transgenes and an internal control. The highest average transgene pollen flow (16\%) was seen at short distances (3-15 $\mathrm{m}$ ), rapidly diminishing to $3 \%$ by a $240 \mathrm{~m}$ distance and continued at this low rate up to the furthest distance assessed $(650 \mathrm{~m})$ from the GM trial. The negative exponential distribution of GM pollination success was similar to that observed in non-GM eucalypt pollen flow studies, indicating that low levels of effective pollination are expected over long distances. To the best of our knowledge, this is the first experimental assessments of realized pollen flow measured by the effective production of seedlings from a genetically modified tree in field conditions.
\end{abstract}

(c) 2016 Elsevier B.V. All rights reserved.

\section{Introduction}

Genetic modification (GM) has been proposed as a complementary technology to conventional and genomic assisted breeding to increase biomass production of intensively managed planted forests with potential for producing more wood on less land (Dubouzet et al., 2013; Harfouche et al., 2011). Forest productivity may also be increased by improving biotic and abiotic stress tolerance. Examples of GM trees expressing abiotic stress-tolerance (Harfouche et al., 2011; Osakabe et al., 2012) and enhanced disease resistance (Haggman et al., 2013) have been reviewed. Of special

\footnotetext{
* Corresponding author at: Instituto de Pesquisas e Estudos Florestais (IPEF) Avenida Pádua Dias 11, Caixa Postal 530, CEP 13400-970 Piracicaba, SP, Brazil.

E-mail address: paulohenrique@ipef.br (Paulo H.M. da Silva).
}

interest have been the cases of genetically engineered resistance to the Dutch elm disease in American elm and chestnut blight resistance in American chestnut (Thompson, 2012). Nevertheless, the deployment of genetically engineered trees has been a controversial issue (Brunner et al., 2007; Haggman et al., 2013). Some concerns put forward about potential damages to the environment have resulted in regulatory, certification and market obstacles, significantly hindering not only the commercial adoption of the technology but also the development of associated science that comes along (Strauss et al., 2015).

Confined field trials are small-scale field experiments carried out to evaluate the performance of genetically modified (GM) trees, providing the key experimental platform to advance their evaluation beyond the laboratory or greenhouse tests. Such trials enable scientists to evaluate the performance of GM material and collect 
data to meet regulatory requirements, including the potential for gene flow by pollen and distance dispersal by seeds, one of the main concerns raised for long lived forest trees (Brunner et al., 2007; Haggman et al., 2013). Such trials also allow the evaluation of the effectiveness of buffer strips around GM tree trials in reducing pollen flow and seedling establishment by seed dispersal outside the trial. Gene flow from tree plantations is one of the paramount processes affecting surrounding cross-compatible plantations and natural populations (DiFazio et al., 2012). This issue becomes significant with the development of GM trees for variable objectives such as disease and pest resistance, wood quality, drought tolerance and fast growth. The potential effects of gene flow by pollen and seed from GM trees to natural or other nonGM planted stands will depend, however, on the traits introduced and the species under scrutiny. Many genes of interest for commercial purposes are likely to present no or very low risk, either because they are very similar to native genes, or because they will be neutral or even reduce tree fitness (Brunner et al., 2007). Furthermore, this issue becomes more relevant when GM trees are deployed in regions that coincide with the center of origin and diversity of the species. When used as exotics, the expected impacts of GM trees on the native flora should be less of a concern due to the absence of naturally occurring cross-compatible forest populations.

Eucalypt trees are the most widely planted hardwoods in the world due to their outstanding ability to adapt, grow and provide quality wood for multiple applications (Myburg et al., 2007; Grattapaglia et al., 2012; Gonçalves et al., 2013). Due to their key role in modern intensive forestry worldwide, they have been an important target for genetic engineering efforts aimed at improving growth, wood quality and frost tolerance. A number of studies have assessed the potential seed-mediated gene flow from planted eucalypts into native forests in Australia in the context of 'genetic pollution' concerns (Barbour et al., 2010; Larcombe et al., 2014). The risk of eucalypt invasiveness by seed-mediated dispersal in exotic environments has also been investigated (Booth, 2012; Callaham et al., 2013; Calviño-Cancela and Rubido-Bará, 2013; Catry et al., 2015; Lorentz and Minogue, 2015; Silva et al., 2016). Pollen-mediated gene flow studies using molecular markers have been carried out mostly in the context of assessing the quality of seed orchard crops and the contamination potential of external pollen sources (Chaix et al., 2003; Grosser et al., 2010) without any particular concern with regard to the distance of gene flow. Early studies of pollen dispersal in E. saligna plantations in Brazil were based on tracking radioactive labeled pollen, revealing effective bee movement up to $100 \mathrm{~m}$ from their hives, with gradually decreasing activity up to a $300 \mathrm{~m}$ distance (Pacheco et al., 1986). Recently, we have investigated pollen-mediated flow and realized reproductive success at increasing distances from the source, across fragmented clonal stands of eucalypts in Brazil by parentage analysis of seedlings using microsatellite markers. We showed that pollination will take place by and large at relatively short distances of less than $200 \mathrm{~m}$, consistent with the expected range of flight of pollinator bees (Silva et al., 2015). Going beyond the measurement of gene flow in natural stands, a spatially explicit landscape model to simulate pollination, dispersal, establishment and mortality, was proposed for Poplar in the US, showing that modeled transgene flow is highly context dependent and influenced by the competitive effect of transgenes, fertility of transgenic trees, plantation rotation length and patterns of selection (DiFazio et al., 2012).

While results of pollen mediated, gene flow studies in eucalypts clearly indicate that pollination will take place up to reasonably limited distances, pollen containment strategies by introducing sterility genes have been considered. Complete prevention of pollen production in greater than $95 \%$ of independently transformed lines was demonstrated in large-scale and multiple-year field tests of eucalypts by genetic modification with a pine male cone-specific promoter, PrMC2, driving a modified barnase coding sequences (Zhang et al., 2012). No studies to date, however, have reported experimental assessments of effective pollen dispersal from GM trees in field conditions. Given the recent Brazilian approval for commercial release of the first GM eucalypt in the world (Nature, 2015), such information should be relevant to complement existing data from molecular marker based pollen dispersal reports. In this study, we investigated wildling seedlings establishment and pollen dispersal from a contained field trial of GM eucalypt in Brazil.

\section{Material and methods}

\subsection{Experimental design and sample collection}

Our study was carried out in a location in Paranapanema, São Paulo state, in southeastern Brazil $\left(23^{\circ} 35^{\prime} \mathrm{S}, 48^{\circ} 03^{\prime} \mathrm{W}, 670 \mathrm{~m}\right.$ of altitude). The area included an experimental GM eucalypt stand established in 2009 using standard silvicultural practices as described earlier (Gonçalves et al., 2013). The experiment involved 1836 trees out of which 1665 were GM and 171 non-GM controls, in a $2.7 \times 2.7 \mathrm{~m}$ spacing. Following the regulatory requirements by CTNBio (Brazilian National Technical Commission for Biosafety) (Normative Resolution No. 6, November 6th, 2008), the trial was surrounded by six border rows of a single non-GM clone and followed by a Brachiaria (signalgrass) field extending up to about $100 \mathrm{~m}$ from the forest stand, except where a non-GM eucalypt plantation had been previously established. To investigate realized transgenic pollen dispersal, open-pollinated seeds were collected from non-GM eucalypt trees including trees in the border rows as well as trees inside an adjacent non-GM eucalypt stand. Seeds were sampled from trees at seven distances from the GM tree stand: 3, 15, 220, 240, 260, 435 and $650 \mathrm{~m}$ (Fig. 1). At each distance, seeds from four randomly selected trees were collected totaling 28 trees. Open pollinated seeds from each sampled tree were planted in a greenhouse and 15 seedlings were randomly sampled per tree for genetic analysis. In total 420 seedlings were analyzed for the presence of transgene sequences. Leaf samples were collected for DNA analysis when the seedlings were 30 days old. Both GM trees and non-GM seed trees are hybrid clones of Eucalyptus urophylla $\times$ Eucalyptus grandis. Outside the experimental GM trial wildling establishment of GM seedlings up to $100 \mathrm{~m}$ from the stand was monitored every three months from 2010 to 2014, starting when the eucalypts initiated seed production (approximately 18 months after planting).

\subsection{Detection of transgenic sequences}

Total genomic DNA extraction was performed using a standard CTAB-based mini-prep protocol as described earlier for Eucalyptus (Grattapaglia and Sederoff, 1994). Two independent DNA extractions were carried out for each seedling on separate days to provide fully replicated results for each seedling to prevent the possibility of labeling error. DNA extractions were carried out in a laminar flow hood to prevent DNA cross contamination among samples. Transgenic sequence detection consisted in the PCR amplification of two specific genomic regions of the inserted transgenic construct. Primers were designed aiming at the detection of PCR products with sizes between 100 and $200 \mathrm{bp}$. Primer pairs were designed targeting two separate transgenic sequences, the neomycin phosphotransferase II gene (nptII) (forward primer: $5^{\prime}$ CAATAGCAGCCAGTCCCTTC-3' and reverse primer: 5'ATGACTGGG CACAACAGACA-3'), and the nopaline synthase terminator (nosterminator) from Agrobacterium tumefaciens (forward primer 5'-G 


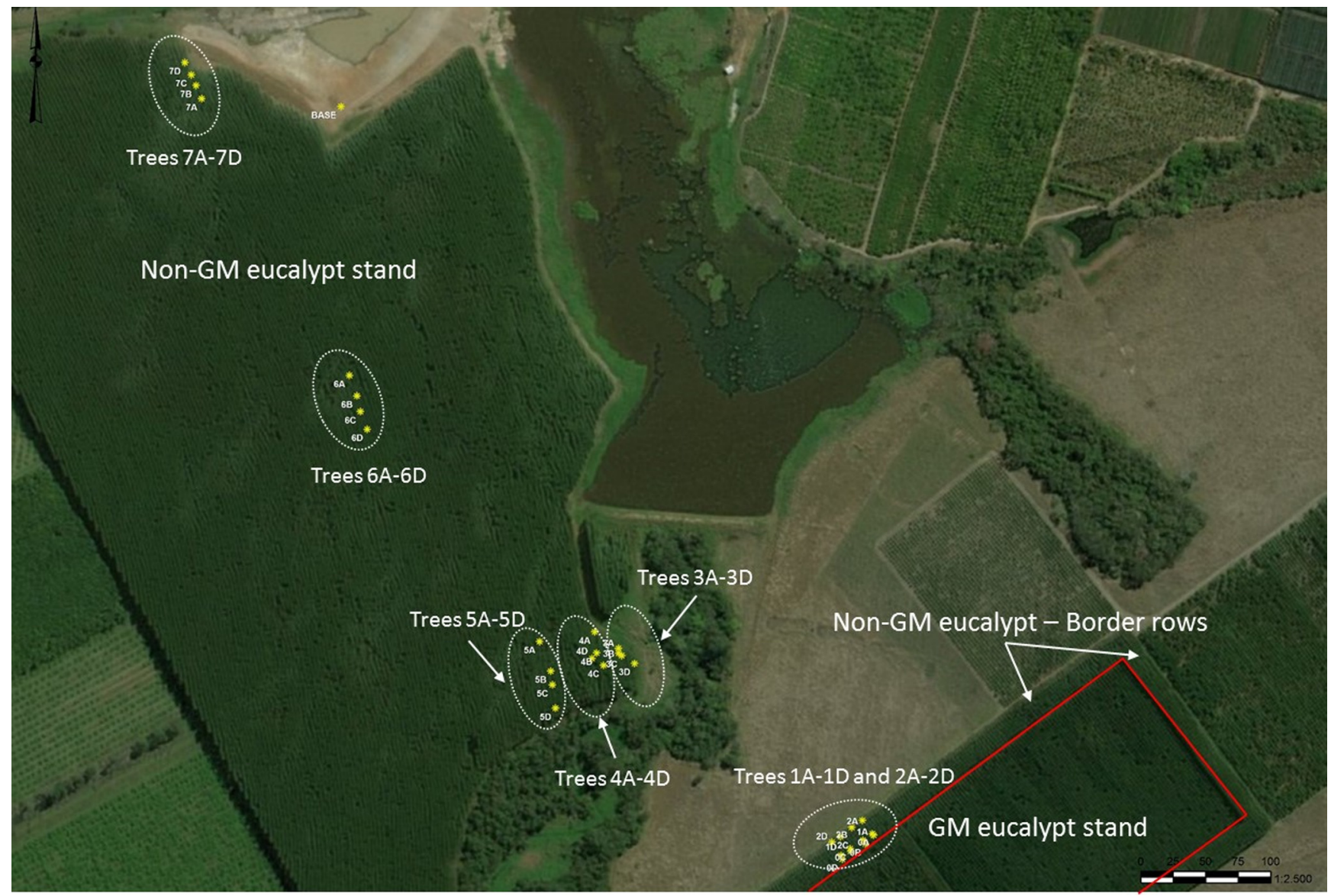

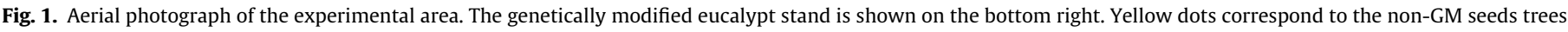

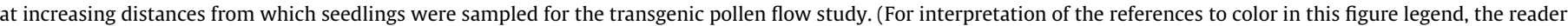
is referred to the web version of this article.)

AATCCTGTTGCCGGTCTT- $3^{\prime}$ and reverse primer 5'-TTGCGCGCTA TATTTTGTTTT- $3^{\prime}$ ). To provide a positive control for PCR amplification and therefore to control for false negatives due to PCR failure, an internal control was used in the form of a Eucalyptus specific microsatellite marker (EMBRA12) developed earlier (Brondani et al., 1998). The forward primers of each one of the three amplified sequences were synthesized with a 6-FAM fluorescent label at the $5^{\prime}$ end for detection during capillary electrophoresis. As positive control for the transgenic sequences, both the original construct and DNA of the GM Eucalyptus pollen donor clone were used, while autoclaved water was used as negative control. PCR reactions of the nptII-nos-EMBRA12 multiplexed system were carried out in a $10 \mu$ l volume containing $1 \mu \mathrm{l}$ of $10 \times$ Qiagen Multiplex PCR Buffer (Qiagen Inc., Valencia, CA, USA), equal concentrations $(0.1 \mu \mathrm{M})$ of all primers and $2.0 \mathrm{ng}$ of genomic DNA. The recommended Qiagen Multiplex PCR Handbook cycling protocol was used with an annealing temperature of $60^{\circ} \mathrm{C}$ and 30 PCR cycles. An aliquot of $1 \mu \mathrm{l}$ of PCR products was mixed with $1 \mu \mathrm{l}$ of freshly prepared ROX-labeled size standard (Brondani and Grattapaglia, 2001) and $10 \mu \mathrm{l}$ of Hi- Di formamide (Applied Biosystems, Foster City, CA, USA). The mixture was electroinjected in an ABI 3100XL genetic analyzer and data collected under dye set D spectral calibration using Genescan and analyzed with Genotyper (Applied Biosystems, Foster City, CA, USA).

\subsection{Data analysis}

The wildling establishment was not subject to statistical analysis since no establishment of eucalypt seedlings was observed. No significant difference in GM seedling frequency was seen among those derived from the closer distances of the border row trees (3 and $15 \mathrm{~m}$ distances), as well as among the medium distances $(220,240$ and $260 \mathrm{~m}$ ) and longer distances (435 and $650 \mathrm{~m})$ in the adjacent non-GM eucalypt stand. Data for these three sets of distances (short, medium and long) were therefore pooled for analysis. Both an ANOVA and a non-parametric Kruskal-Wallis test were used to test for significant difference in GM seedling frequency among the tree distances and a negative exponential function $\left(y=a x^{-b}\right)$ was fitted to explain the distance effect, where $\mathrm{y}=\mathrm{GM}$ seedlings rate; $\mathrm{x}=$ distance $(\mathrm{m}) ; \mathrm{a}=$ coefficient; and $\mathrm{b}=$ exponent.

\section{Results}

No eucalypt wildlings were found during the four years of monitoring. The only woody species observed were a single Pinus sp. tree and several Ouratea hexasperma bushes. In the GM pollen flow assessment, a significant difference in the frequency of realized GM pollen flow, measured by genotyping the offspring generation, was seen among the three sets of distances (short, medium and long) using both an ANOVA $(\mathrm{F}=4.45$; $\mathrm{p}$ value $=0.045)$ and a nonparametric test $(p$ value $=0.044)$. The difference observed was largely due to the difference between the short and the other two sets of distances (Table 1). Considerable variation in the frequency of GM seedlings was seen among the four seed trees within the same distance from the pollen source. This variation was greatest at the $15 \mathrm{~m}$ distance, with a tree producing zero GM offspring and another with $50 \%$ of its offspring being GM. At longer distance, 
Table 1

Counts and percentages of genetically modified (GM) seedlings observed at increased distances from the donor GM eucalypt stand.

\begin{tabular}{|c|c|c|c|c|c|}
\hline \multirow[t]{2}{*}{ Treatment } & \multirow[t]{2}{*}{ Distance } & \multirow[t]{2}{*}{ Tree } & \multicolumn{3}{|l|}{ Seedlings } \\
\hline & & & Evaluated & Total GM & GM rate \\
\hline \multirow[t]{9}{*}{ Short distance } & \multirow[t]{4}{*}{$3 \mathrm{~m}$} & $1 \mathrm{~A}$ & 15 & 2 & $13 \%$ \\
\hline & & 1B & 15 & 2 & $13 \%$ \\
\hline & & $1 C$ & 15 & 1 & $7 \%$ \\
\hline & & $1 \mathrm{D}$ & 15 & 1 & $7 \%$ \\
\hline & \multirow[t]{5}{*}{$15 \mathrm{~m}$} & $2 \mathrm{~A}$ & 15 & 1 & $7 \%$ \\
\hline & & $2 \mathrm{~B}$ & 15 & 0 & $0 \%$ \\
\hline & & $2 \mathrm{C}$ & 14 & 7 & $50 \%$ \\
\hline & & $2 \mathrm{D}$ & 15 & 5 & $33 \%$ \\
\hline & & Average & 119 & 19 & $16 \%$ \\
\hline \multirow[t]{13}{*}{ Medium distance } & \multirow[t]{4}{*}{$220 \mathrm{~m}$} & $3 \mathrm{~A}$ & 15 & 0 & $0 \%$ \\
\hline & & $3 B$ & 15 & 0 & $0 \%$ \\
\hline & & $3 C$ & 15 & 0 & $0 \%$ \\
\hline & & $3 \mathrm{D}$ & 15 & 2 & $13 \%$ \\
\hline & \multirow[t]{4}{*}{$240 \mathrm{~m}$} & $4 \mathrm{~A}$ & 15 & 0 & $0 \%$ \\
\hline & & $4 \mathrm{~B}$ & 15 & 2 & $13 \%$ \\
\hline & & $4 C$ & 14 & 0 & $0 \%$ \\
\hline & & $4 \mathrm{D}$ & 14 & 0 & $0 \%$ \\
\hline & \multirow[t]{5}{*}{$260 \mathrm{~m}$} & $5 \mathrm{~A}$ & 15 & 0 & $0 \%$ \\
\hline & & $5 B$ & 15 & 1 & $7 \%$ \\
\hline & & $5 C$ & 15 & 0 & $0 \%$ \\
\hline & & $5 \mathrm{D}$ & 15 & 0 & $0 \%$ \\
\hline & & Average & 178 & 5 & $3 \%$ \\
\hline \multirow[t]{9}{*}{ Long distance } & \multirow[t]{4}{*}{$435 \mathrm{~m}$} & $6 \mathrm{~A}$ & 15 & 1 & $7 \%$ \\
\hline & & $6 \mathrm{~B}$ & 15 & 0 & $0 \%$ \\
\hline & & $6 C$ & 15 & 0 & $0 \%$ \\
\hline & & $6 \mathrm{D}$ & 15 & 1 & $7 \%$ \\
\hline & \multirow[t]{5}{*}{$650 \mathrm{~m}$} & $7 \mathrm{~A}$ & 15 & 2 & $13 \%$ \\
\hline & & $7 \mathrm{~B}$ & 15 & 0 & $0 \%$ \\
\hline & & $7 C$ & 15 & 0 & $0 \%$ \\
\hline & & $7 \mathrm{D}$ & 15 & 0 & $0 \%$ \\
\hline & & Average & 120 & 4 & $3 \%$ \\
\hline
\end{tabular}

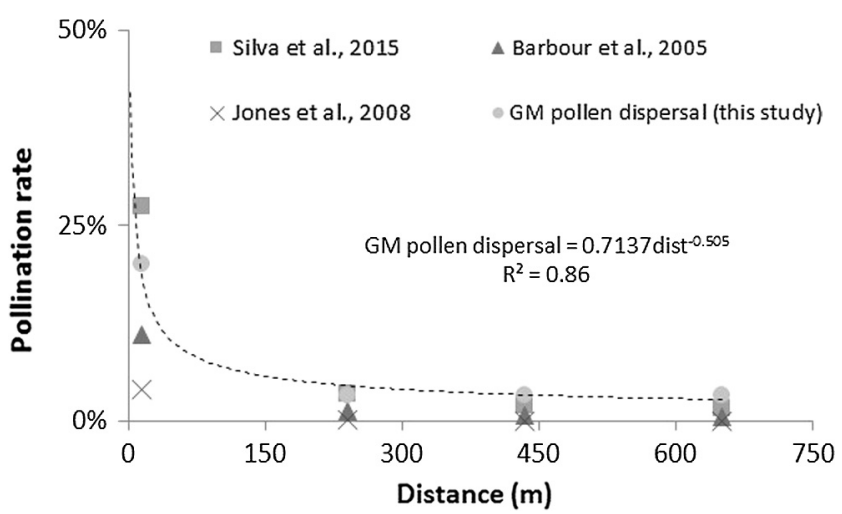

Fig. 2. Decay of the percentage of pollination success at increasing distances from the donor GM eucalypt stand observed in this study (dotted line) overlaid with results from previous pollen dispersal distance studies in Eucalyptus.

variation was also seen with only one tree out of four at 220, 240, 260 and $650 \mathrm{~m}$ distance from the pollen donor producing GM seedlings (Table 1). A negative exponential model was fitted with a fattail distribution suggesting a leptokurtic pattern of transgene flow (Fig. 2). The highest effective pollination rate was seen at short distances, averaging $16 \%$ of the offspring deemed as GM, but diminished to $3 \%$ by a medium distance (around $240 \mathrm{~m}$ ) and continued at this low rate to further distances from the GM pollen donor trees.

\section{Discussion}

\subsection{Eucalyptus wildling establishment}

More than 200 eucalypt species have been evaluated in 92 countries around the world in the last 100 years (Eldridge et al.,
1993), generally showing very limited invasive potential (Booth, 2012). The adaptation of eucalypts to fire, particularly the use of protective seed capsules, the dispersal of seed over comparatively short distances, the small size of seed, and their limited viability under natural conditions make eucalypts not very effective as invasive species (Booth, 2012, 2014; Booth et al., 2015). The majority of seeds are dispersed within just a few meters of the seed trees (e.g. 1-2 canopy heights), keeping the offspring plants close to their mother tree (Jones et al., 2007; Field et al., 2011; Breed et al., 2015). Wildling establishment of seedlings could occur in specific conditions, increasing with plantation age and at sites with regular rainfall and where burning has occurred (Larcombe et al., 2013). Germination and survival is higher in disturbed soil and with adequate condition establishment may occur close to the stand (Lorentz and Minogue, 2015). Results of our study corroborate these general expectations of the very limited ability of eucalypt to prosper as wildlings. No seedling establishment was observed during four years of monitoring. Furthermore, the surrounding vegetation composed mainly of Brachiaria, a very strong competitive grass, likely contributed to decreasing the opportunity for natural regeneration of seedlings as previously reported in commercial stands of non-GM eucalypts in Southeaster Brazil (Silva et al., 2011). Even under adequate environmental conditions, in the presence of competition by ecologically adapted species, eucalypts seedling establishment is less likely than that of other local tree species (Skinner et al., 2010). Furthermore, in monoclonal plantations, the majority of seeds will be originated from mating between genotypically identical near-neighbor trees, which effectively corresponds to self-mating. Eucalypts are known to display strong inbreeding depression (Griffin and Cotterill, 1988; Eldridge et al., 1993; Costa e Silva et al., 2011; Hedrick et al., 2015), such that those few inbred seedlings that manage to germinate, will eventually be outcompeted and most likely succumb within 
the first few months. However if some form of disturbance takes place (e.g. fire), the establishment of outbred GM seedlings could occur (Larcombe et al., 2013; Silva et al., 2016). Therefore, wildling regeneration monitoring is technically warranted throughout the rotation age of the plantation, usually 5-7 years in tropical conditions.

\subsection{Pollen flow from GM trees}

Based on our experimental design of 60 seedlings produced by four trees sampled in each distance we estimated an average of $3.3 \%$ of the seedlings bearing the transgene at $240 \mathrm{~m}$ distance form the GM pollen source. However only seedlings from one of the four trees sampled at this and further distances were GM indicating a considerable tree to tree variation likely due to variable flowering synchrony. Our estimate of pollen flow is within the same range of previous estimates obtained in pollen flow studies in natural stands suggesting, as expected, that no particular difference exists between GM and non-GM pollen flow. Barbour et al. (2005) observed an average of $7.2 \%$ pollination success by plantation eucalypts within a $100 \mathrm{~m}$ distance into a native stand, diminishing to $0.7 \%$ by $200-300 \mathrm{~m}$ and continuing at this level for longer distances. Thus, pollen flow from planted eucalypts stands could modify the genetic pool in the surrounding area of native eucalypts at such distances. Potts and Reid (1988) found 200-300 m of effective pollination distance in natural areas of eucalypts. In an earlier gene flow study among fragmented clonal stands, we also found differences in the effective pollination success of incoming pollen among receiving seed trees at a similar distance range from the pollen source (Silva et al., 2015). In our assessment of GM pollen flow, when pollination success was averaged across seed trees within a single distance, we saw a slightly higher frequency of GM seedlings production from seed trees at $15 \mathrm{~m}(23 \%)$ when compared to trees at the shortest distance of $3 \mathrm{~m}(10 \%)$. However, no significant difference was detected between these two closer distances due to the large variation observed among seed trees (Table 1). These results are consistent with other studies where an average pollination distance of $58 \mathrm{~m}$ was estimated with high variation in pollination success among trees at the same distance from the pollen source (Jones et al., 2008), and the observation of $50 \%$ of pollen coming from more than $40 \mathrm{~m}$ distance (Burczyk et al., 2002). Bearing in mind that each pollen flow study is effectively unique, where environmental conditions and food availability for pollinators influence pollination rates, one should expect results from different studies to differ. However, when we jointly plotted the results from different eucalypt pollen flow studies, differences observed were marginal. All studies to date revealed a very consistent trend (Fig. 2): a high rate of successful pollen flow at short distances $(<100 \mathrm{~m})$ with a rapid and considerable decrease at medium distances (100-200 $\mathrm{m}$ ) that continues as such for long distances, up to $650 \mathrm{~m}$ in our present study.

\subsection{Main considerations}

Our results of four years of monitoring potential eucalypt wildling establishment substantiate previous reports showing that eucalypts seedlings from commercial stands are not expected to thrive in the standard environmental conditions used for commercial eucalypt plantation in tropical areas. Poor seed dispersal of eucalypts and the adoption of a $100 \mathrm{~m}$ border area with an aggressive grass surrounding the stand should ensue a risk practically close to zero. These results could contribute to future revisions of the containment procedures for field trials in Brazil, including the potential mitigation of current containment demands. Most importantly, our study provides the first experimental data on GM eucalypt pollen flow in field conditions, corroborating the same general behavior of pollen movement reported in previous assessments carried out in non-GM eucalypt stands. With respect to pollen flow, since there is virtually no propagation from seeds obtained from commercial plantations, the Brazilian regulatory authority has determined that an important consideration regarding GM eucalypt stands is that they should be kept isolated from seed orchards. Based on our data on GM pollen dispersal distance, complete exclusion of transgenes from seed orchards or commercial stands will require separation distances greater than $650 \mathrm{~m}$. A more reasonable measure would be, however, to set a maximum acceptable level of transgene presence that would in turn determine a minimum recommended distance between GM and non GM stands or seed orchards.

\section{Acknowledgement}

We would like to thank all the people involved on this project, especially Dr. Les Pearson and Dr. Luciana Di Ciero for their support and their suggestions on the manuscript, and ArborGen for enabling the study.

\section{References}

Barbour, R.C., Potts, B.M., Vaillancourt, R.E., 2005. Pollen dispersal from exotic Eucalyptus plantations. Cons. Genet. 6, 253-257.

Barbour, R.C., Wise, S.L., McKinnon, G.E., Vaillancourt, R.E., Williamson, G.J., Potts, B. M., 2010. The potential for gene flow from exotic Eucalyptus plantations into Australia's rare native Eucalyptus. For. Ecol. Manage. 260, 2079-2087.

Brondani, R.P.V., Brondani, C., Tarchini, R., Grattapaglia, D., 1998. Development, characterization and mapping of microsatellite markers in Eucalyptus grandis and E. urophylla. Theor. Appl. Genet. 97, 816-827.

Brondani, R.P., Grattapaglia, D., 2001. Cost-effective method to synthesize a fluorescent internal DNA standard for automated fragment sizing. Biotechniques 31, 793-795.

Breed, M.F., Ottewell, K.M., Gardner, M.G., Marklund, M.H.K., Stead, M.G., Harris, J.B. C., Lowe, A.J., 2015. Mating system and early viability resistance to habitat fragmentation in a bird-pollinated eucalypt. Heredity 115, 100-107.

Booth, T.H., 2012. Eucalyptus and their potential for invasiveness particularly in frost-prone regions. Int. J. Forestry Res. 7. http://dx.doi.org/10.1155/2012/ 837165 Article ID 837165.

Booth, T.H., 2014. Modern tree colonisers from Australia into the rest of the world. In: Prins, H.H.T., Gordon, I.J. (Eds.), Invasion Biology and Ecological Theory: Insights from a Continent in Transformation. Cambridge University Press, p. 528.

Booth, T.H., Broadhurst, L.M., Pinkard, E., Prober, S.M., Dillon, S.K., Bush, D., Young, A. G., 2015. Native forests and climate change: Lessons from Eucalyptus. For. Ecol. Manage. 347, 18-29.

Brunner, A.M., Li, J., DiFazio, S.P., Shevchenko, O., Montgomery, B.E., Mohamed, R., Wei, H., Ma, C., Elias, A.A., VanWormer, K., Strauss, S.H., 2007. Genetic containment of forest plantations. Tree Genet. Gen. 3, 75-100.

Burczyk, J., Adams, W.T., Moran, G.F., Griffin, A.R., 2002. Complex patterns of mating revealed in a Eucalyptus regnans seed orchard using allozyme markers and the neighbourhood model. Mol. Ecol. 11, 2379-2391.

Callaham, M.A.J., Stanturf, J.A., Hammond, W.J., Rockwood, D.L., Wenk, E.S., O’Brien, J.J., 2013. Survey to evaluate escape of Eucalyptus spp. seedlings from plantations in Southeastern USA. Int. J. Forestry Res., 10

Calviño-Cancela, M., Rubido-Bará, M., 2013. Invasive potential of Eucalyptus globulus: seed dispersal, seedling recruitment and survival in habitats surrounding plantations. For. Ecol. Manage. 305, 129-137.

Catry, F.X., Moreira, F., Deus, E., Silva, J.S., Águas, A., 2015. Assessing the extent and the environmental drivers of Eucalyptus globulus wildling establishment in Portugal: results from a countrywide survey. Biol. Inv. 17, 3163-3181.

Costa e Silva, J., Hardner, C., Tilyard, P., Potts, B.M., 2011. The effects of age and environment on the expression of inbreeding depression in Eucalyptus globulus. Heredity 107, 50-60.

Chaix, G., Gerber, S., Razafimaharo, V., Vigneron, P., Verhaegen, D., Hamon, S., 2003. Gene flow estimation with microsatellites in a Malagasy seed orchard of Eucalyptus grandis. Theor. Appl. Gen. 107, 705-712.

DiFazio, S.P., Leonardi, S., Slavov, G.T., Garman, S.L., Adams, W.T., Strauss, S.H., 2012. Gene flow and simulation of transgene dispersal from hybrid poplar plantations. New Phytol. 193, 903-915.

Dubouzet, J.G. Strabala, TJ., Wagner, A., 2013. Potential transgenic routes to increase tree biomass. Plant Sci. 212, 72-101.

Eldridge, K., Davidson, J., Harwood, C., van Wyk, G., 1993. Eucalypt Domestication and Breeding. Clarendon Press, Oxford, UK.

Field, D.L., Ayre, D.J., Whelan, R.J., Young, A.G., 2011. Patterns of hybridization and asymmetrical gene flow in hybrid zones of the rare Eucalyptus aggregata and common E. rubida. Heredity 106, 841-853. 
Gonçalves, J.L.M., Alvares, C.A., Higa, A.R., Silva, L.D., Alfenas, A.C., Stahl, J., Ferraz, S. F.B., Lima, W.P., Brancalion, P.H.S., Hubner, A., Bouillet, J.P.D., Laclau, J.P., Nouvellon, Y., Epron, D., 2013. Integrating genetic and silvicultural strategies to minimize abiotic and biotic constraints in Brazilian eucalyptus plantations. Forest Ecol. Manage, 301, 6-21.

Grattapaglia, D., Sederoff, R., 1994. Genetic linkage maps of Eucalyptus grandis and Eucalyptus urophylla using a pseudo-testcross: mapping strategy and RAPD markers. Genetics 137, 1121-1137.

Grattapaglia, D., Vaillancourt, R., Shepherd, M., Thumma, B., Foley, W., Külheim, C., Potts, B., Myburg, A., 2012. Progress in Myrtaceae genetics and genomics: eucalyptus as the pivotal genus. Tree Genet. Gen. 8, 463-508.

Griffin, A.R., Cotterill, P.P., 1988. Genetic-variation in growth of outcrossed, selfed and open-pollinated progenies of Eucalyptus regnans and some implications for breeding strategy. Silvae Genet. 37, 124-131.

Grosser, C., Potts, B.M., Vaillancourt, R.E., 2010. Microsatellite based paternity analysis in a clonal Eucalyptus nitens seed orchard. Silvae Genet. 59, 57-62.

Haggman, H., Raybould, A., Borem, A., Fox, T., Handley, L., Hertzberg, M., Lu, M.Z., Macdonald, P., Oguchi, T., Pasquali, G., Pearson, L., Peter, G., Quemada, H. Seguin, A., Tattersall, K., Ulian, E., Walter, C., McLean, M., 2013. Genetically engineered trees for plantation forests: key considerations for environmental risk assessment. Plant Biotechnol. J. 11, 785-798.

Harfouche, A., Meilan, R., Altman, A., 2011. Tree genetic engineering and applications to sustainable forestry and biomass production. Trends Biotechnol. 29, 9-17.

Hedrick, P.W., Hellsten, U., Grattapaglia, D., 2015. Examining the cause of high inbreeding depression: analysis of whole-genome sequence data in 28 selfed progeny of Eucalyptus grandis. New Phytol. 209, 600-611.

Jones, T.H., Vaillancourt, R.E., Potts, B.M., 2007. Detection and visualization of spatial genetic structure in continuous Eucalyptus globulus forest. Mol. Ecol. 16, 697707.

Jones, M.E., Shepherd, M., Henry, R., Deves, A., 2008. Pollen flow in Eucalyptus grandis determined by paternity analysis using microsatellite markers. Tree Genet. Geno. 4, 37-47.

Larcombe, M.J., Silva, J.S., Vaillancourt, R.E., Potts, B.M., 2013. Assessing the invasive potential of Eucalyptus globulus in Australia: quantification of wildling establishment from plantations. Biol. Invas. 15, 2763-2781.
Larcombe, M.J., Barbour, R.C., Vaillancourt, R.E., Potts, B.M., 2014. Assessing the risk of exotic gene flow from Eucalyptus globulus plantations to native E. ovata forests. For. Ecol. Manage. 312, 193-202.

Lorentz, K.A., Minogue, P.J., 2015. Potential invasiveness for eucalyptus species in Florida. Inv. Plant Sci. Manage. 8, 90-97.

Myburg, A.A., Potts, B.M., Marques, C.M., Kirst, M., Gion, J.M., Grattapaglia, D. Grima-Pettenati, J., 2007. Eucalyptus. In: K.C. (Ed.), Genome Mapping and Molecular Breeding in Plants. Springer, New York, NY, USA, pp. 115-160.

Nature News, 2015. Brazil approves transgenic eucalyptus. Nat. Biotechnol. 33, 577. http://dx.doi.org/10.1038/nbt0615-577c.

Osakabe, Y., Kawaoka, A., Nishikubo, N., Osakabe, K., 2012. Responses to environmental stresses in woody plants: key to survive and longevity. J. Plant Res. 125, 1-10.

Pacheco, I.A., Kageyama, P.Y., Wiendl, E.M., Berti Filho, E., 1986. Estudo da dispersãode pólen de Eucalyptus saligna Smith por abelhas Apis mellifera L. utilizando-seo radio fósforo 32P. Scientia Forestalis 34, 47-52.

Potts, B.M., Reid, J.B., 1988. Hybridization as a dispersal mechanism. Evolution 42, 1245-1255.

Silva, P.H.M., Poggiani, F., Sebbenn, A.M., Mori, E.S., 2011. Can Eucalyptus invade native forest fragments close to commercial stands? For. Ecol. Manage. 261, 2075-2080.

Silva, P.H.M., Sebbenn, A.M., Grattapaglia, D., 2015. Pollen-mediated gene flow across fragmented clonal stands of hybrid Eucalyptus in an exotic environment. For. Ecol. Manage. 356, 293-298. http://dx.doi.org/10.1016/j.foreco.2014.12.005.

Silva, P.H.M., Bouillet, de Paula, R.C., 2016. Assessing the invasive potential of commercial Eucalyptus species in Brazil: germination and early establishment. For. Ecol. Manage. 374, 129-135.

Skinner, A.K., Lunt, I.D., Mcintyre, S., Spooner, P.G., Lavorel, S., 2010. Eucalyptus recruitment in degraded woodlands: no benefit from elevated soil fertility. Plant Ecol. 208, 359-370.

Strauss, S.H., Costanza, A., Seguin, A., 2015. Biotechnology. Genetically engineered trees: paralysis from good intentions. Science 349, 794-795.

Thompson, H., 2012. Plant science: the chestnut resurrection. Nature 490, 22-23.

Zhang, C.S., Norris-Caneda, K.H., Rottmann, W.H., Gulledge, J.E., Chang, S.J., Kwan, B. Y.H., Thomas, A.M., Mandel, L.C., Kothera, R.T., Victor, A.D., Pearson, L., Hinchee M.A.W., 2012. Control of pollen-mediated gene flow in transgenic trees. Plant Phys. 159, 1319-1334. 